9. Якупко О.Ф., Мюллер Б., Романов В.П., 1988, «Математическая интерпретация типологических показателей озер Белоруссии», Вестник Белорусского университета, сер.2, 2, с. 51-56.

\title{
VIENOTAS VIDES AIZSARDZĪBAS VADĪBAS SISTËMAS IZVEIDE
}

\author{
A.ROSKA, A.JAUNZEME \\ Vides valsts inspekcija, \\ Rūpniecības iela 25, Rīga, Latvija, LV - 1877 \\ T.: 7325091, F.: 7243077
}

Latvijā vides aizsardzības jomā ir izstrādāta virkne tiesību aktu un normatīvo dokumentu, tomēr joprojām nav izstrādāts vienots mehānisms šo dokumentu izpildes nodrošināšanai uz vietām un it sevišķi rūpniecības un lauksaimniecības uzņēmumos.

Jau 1995.gadā tika izstrādāts un apstiprināts "Vides aizsardzības politikas plāns Latvijai", kurā formulēti mūsu vides aizsardzības politikas mērķi un uzskaitīti principi, uz kuriem šai politikai jābalstās, kā arī līdzekḷi, ar kuriem tā ieviešama.

Lai veiktu savas darbības saskaņā ar "Vides aizsardzības politikas plānu Latvijai" un īstenotu tajā izvirzītos uzdevumus, katram uznēemumam ir jāizstrādā savs vides politikas plāns pietiekoši ilgam laika periodam, jānosprauž vadlīnijas izvirzîto vides aizsardzības mērķu sasniegšanai, kā arī jāizstrādā rīcības programma, ja ne vides stāvoḳ̣a uzlabošanai, tad vismaz tā saglabāšanai.

Šo mērki vislabāk varētu sasniegt, ieviešot starptautisko standartu ISO 14001, kā arī Eiropas Savienības akceptēto vides menedžmenta sistēmas aprakstu.

ISO 14001 ir standarts par vides pärvaldību, ko Eiropas standartizācijas komiteja apstiprinājusi 1996.gada 21.augustā. Šim standartam kopš tā apstiprināšanas vienmêr ir bijusi nozīmīga loma, lai veicinātu rüpniecības uzņēmumus un citas organizācijas darboties un attīstīties videi draudzīgã veidā.

Svarīgi atzīmēt, ka vides pārvaldības sistēma ir process, kas nebeidzas kaut kādā noteiktā uzñēmuma attīstības stadijā, tas nepārtraukti mainās un attīstās vienlaicīgi ar uzņèmumu.

Pirms uzņēmums uzsāk darbu pie ISO 14001 standarta ieviešanas, ir jāsastāda sākotnējais vides pārskats. Izstrādājot pārskatu, uzmanība galvenokārt jāpievērš sekojošiem aspektiem:

- vides aizsardzības likumdošanas prasības,

- darbibu un produkcijas veidu noteikšana, kuri tieši vai netieši atstāj ietekmi uz vidi,

- patreizējo vides pārvaldības pasākumu izvērtējums.

Pārskatu var izstrādāt uzņēmuma darbinieki, vai arī pieaicinātie eksperti. Pārskatam jāsniedz plašs raksturojums par visa uzņēmuma darbību, un tas ir pamats, lai apspriestu vides aizsardzības darbu uznēemumā nākotnē.

Svarīgi ir noteikt uznēemuma darbībā tos posmus jeb vājās vietas, kur ietekme uz vidi ir vislielākā. Daudziem uzņēmumiem būtiska problēma vides pārskata sastādīšanā ir zināšanu trūkums par to, kā ražošanas process un saražotã produkcija ietekmē vidi. 
Pārskatā būtu vēlams ietvert sekojošus jautājumus:

- uzñēmuma struktūra, izvietojums un veikto vides aizsardzības pasākumu apraksts;

- uzņēmuma juridiskais statuss, pakḷaušanās vides aizsardzības likumdošanas prasībām;

- ūdens un gaisa piesārņojuma avoti un zināmie piesārnojuma apjomi;

- radīto atkritumu veidi un apjomi, to izvietojums, pārstrādes iespējas;

- izlietoto izejmateriālu veidi un apjomi;

- izmantotās enerǵijas veidi un apjomi;

- uzņēmumā izmantotās ķīmiskās vielas, to veidi un apjomi;

- darba aizsardzības normu ievērošana (troksnis u.c.).

Kā jau iepriekš minēts, sekmīgai vides aizsardzības darba veikšanai svarīgs solis ir uzņēmuma vides politikas izstrāde. To nosaka uzņēmuma administrācija augstākajā lìmenī, un tai ir jābüt saskaņā ar valsts vides politiku. Vides politika nosaka uzņëmuma darbïbas vispārējos virzienus un principus.

tā:

Uznēmuma vadība apstiprina uzñēmuma vides politiku un apņemas nodrošināt, lai

- atbilstu uzñēmuma darbības, produkcijas vai pakalpojumu veidam, mērogam un ietekmei uz vidi;

- ietvertu saistības veikt ilgstošu vides stāvokḷa uzlabojumu un piesārņojuma novēršanu;

- izskatītu iespējas jaunu videi draudzīgu tehnoloǵiju ieviešanā;

- ietvertu saistības ievērot atbilstošos vides aizsardzības normatīvos aktus, kā arī citas prasības, kuras tiek uzstādītas uznēmumam;

- veidotu shēmu vides mērķ̧u un uzdevumu noteikšanai un pārbaudei;

- tiktu dokumentēta, ieviesta un realizēta, kā arī novadìta līdz visiern darbiniekiem;

- bütu pieejama plašai sabiedribai;

- garantētu nepārtrauktu ilgstošu uzņēmuma darbības uzlabošanu.

Uzṇemuma vides politika ir svarīgākais elements uzņēmuma tēla veiđošanā attiecība pret apkārtējo vidi. Ši iemesla dēl uzṇemumi bieži vien priekšroku dod isai un kodolīgai politikai, kas ir uzskatāma, skaidra un viegli uztverama.

Šajā piemērā var redzēt isu un konkrētu vides politikas plānu.

\section{Mẽs apnemamies}

\section{uzlabot darbību,}

- cenšoties sasniegt pasaules klases standartus,

- paklauties esošajai vides aizsardzības likumdošanai,

- meklët lïdzekļus, lai nepārtraukti uzlabotu mūsu darbu vides aizsardzībā,

- piedalīties jaunu standartu izstrādāšanā;

minimizêt ietekmi,

- cenšoties arvien vairāk samazināt kaitīgo/nevēlamo ietekmi uz vidi,

- darbojoties, lai nepielautu negadijumus, kas var ietekmēt vides kvalitāti, un nekavējoties reaǵējot, ja tādi atgadās,

- atlasīt, apieties un izmantot produkciju un izejvielas atbilstoši vides prasībām;

uzturēt sakarus,

- plaši konsultējoties, lai noteiktu sabiedrības vēlmes,

- publicēt mūsu politikas plānu, mērķus un pasākumus,

- ar programmu palīdzību, kas piesaista piegädātājus un partnerus müsu vides mèrkiem;

\section{samazinät patērinu,}

- reciklizējot un atkal izmantojot izejvielas, kad vien tas ir ekonomiski pamatojams un iespējams, 
- samazinot radīto atkritumu apjomu un izejvielu patērinu visos müsu darbūbas aspeltos.

Lai uzņēmumā izveidotu vides pārvaldības sistēmu, svarīgi ir pãrrunāt un izlemt, kas uznēmumā atbildēs par vides problēmām. Standarts ISO 14001 nosaka, ka uzṇēmuma vadỉbai jānodrošina resursi, kas ir būtiski vides pārvaldības sistēmas ieviešanai un kontrolei. Uzņēmuma vadībai jānozīmē speciāls pārstāvis, kuram neatkarīgi no pārējiem pienākumiem ir jābūt pilnvaräm, lai nodrošinātu, ka vides pārvald̄̄bas sistēmas prasības tiek ieviestas un realizētas atbilstoši paredzētajam. Te ietilpst arī pienākums ziņot vadībai par vides pārvaldības darba izpildi.

Pasaules praksē lielos uzñēmumos parasti ir speciāla struktūrvienība, kas nodarbojas ar vides, veselības aizsardzỉbas un darba drošības problēmām. Tā parasti realizē arī vides pārvaldības sistēmu. Mazos uzp̧ēmumos nav nepieciešams radīt speciālu vides aizsardzības struktūiru. Parasti ražošanas iecirkṇa vadītājs vai arī kāds cits, kas ir atbildīgs par vides aizsardzības problēmām, uznemas vides pārvaldības sistēmas koordinatora pienākumus.

Jebkurā gadijumā uzņēmumā jābūt vismaz vienai personai, kas ir apmācīta, kā vides pārvaldības sistēma darbojas un kā to ieviest.

Ir jānem vērā, ka vides pārvaldības sistēmas ieviešana prasa lielus finansiālus ieguldījumus, kuru atgūšana ir iespējama tikai pēc vairākiem gadiem. Vides pārvaldības sistēmas piln̄̄gai ieviešanai nepieciešami aptuveni viens līdz divi gadi.

Nākošais uzṇēmuma uzdevums ir precīzäk definēt, kā tas ieviesīs vides politikas plānu:

- jāsastāda saraksts par likumdošanas prasībām attiecībā uz uzñēmuma vides aizsardzïbas pasākumiem;

- jādefinē vides aizsardzības aspelti attiecībā uz uzñēmuma darbību;

- no augstāk minētajiem vides aspektiem jāsastāda nozīmīgāko aspektu saraksts, ietverot tos, kam galvenā ietekme uz vidi;

- jānosaka vides aizsardzības mērki un uzdevumi;

- jāizveido vides pārvaldības programma.

Uzñēmumam jāzina, kādas likumdošanas prasības skar uzṇēmuma darbību un jāpārzina atbilstošā likumdošana. Nepietiek apgalvot, ka "mēs ievērojam likumu", bet jāvar norädīt, kurš likuma pants tieši skar tā darbību. Uzṇēmums nedrīkst nonākt konflikta situācijā ar normatîvajiem tiesību aktiem.

Ir jāpārzina, kurus tā darbības, produkcijas un pakalpojumu vides aspektus tas var kontrolēt un attiecībā uz kuriem tas būs iespējams nākotnē. Tādējādi būs iespējams noteikt, kuriem no aspektiem būs nozīmīga ietekme uz vidi. Vides aspektu noteikšana ir ilgstošs process, kas nosaka iepriekšejo, patreizējo un potenciālo uzṇēmuma darbības ietekmi uz vidi.

Vides aspektu noteikšanu un ar to saistītās ietekmes uz vidi izvērtēšanas procesu var veikț sekojoši:

- atlasa darbibu, produktu vai pakalpojumu veidu;

- nosaka darbibbas, produkta vai pakalpojuma vides aspektus;

- nosaka vides aspektu ietekmi uz vidi;

- izvērtē, vai konkrētais vides aspekts ir nozīmīgs.

Praktiski to veic, izskatot uzn̄ēmuma darbu un atzīmējot visus darbības virzienus, piemēram, enerǵijas ražošana, transports, kancelejas darbi, vadība, uzglabāšana un ražošana. Izvēlas vienu no šiem virzieniem un sāk ar vides aspektu un to ietekmes uz vidi noteikšanu. Pēc tam izvērtē, kuri aspekti uzskatāmi par nozīmīgākajiem. Ir jāṇem vērā:

- ietekmes mērogs un smagums; 
- ietekmes varbūtïba un ilgums.

Veicot izvērtēšanu, ir jāapsver:

- potenciālā iespēja nonākt likumdošanas iedarbības sfērä;

- ietekmes samazināšanas grūtribas un izmaiņu izmaksas;

- ietekme uz uzņēmuma tirgus attiecībām un uzṇēmuma tēlu sabiedrỉbas acīs.

Palīdzỉbu izvērtēšanas veikšanā var sniegt neatkarīga ekspertīze vai arī kāda vides konsultantu grupa.

Izdalītie nozīmīgākie aspekti jānem vērā, nosakot uzņ̄ēmuma mērķus un uzdevumus, un tie jāiestrādā vides pārvald̄̄bas programmā.

ISO standarts nosaka, ka uznēmumam jãveic vides mērku un uzdevumu dokumentācija. Kad tiek nosprausti pārskata mērķi un uzdevumi, jāapsver vides politikas, likumdošanas un citas prasības, kā arī augstāk minētie nozīmīgākie vides aspekti, tehnologijas izvēle, finansiāläs darbübas un tirgus prasības.

Katram mërkim ir jänosaka vides uzdevumi. Tos var izmantot par pamatu vides pasākumu izvërtēšanas sistēmai un sniegt informāciju par vides pārvaldības sasniegtajiem rezultātiem.

Vides pārvaldības programmai jāatbilst visiem uzņēmumā noteiktajiem mērksiem un uzdevumiem. Programmai jābüt integrētai uzņēmuma stratếgiskajā plānā. Vides pārvaldības programmā jābūt ietvertam laika sadalījumam, resursiem un atbildīgajiem par mërķu un uzdevumu izpildi.

Daudzos gadījumos ieteicams izstrādăt kā ilgtermiņa, tā arī istermina vides programmas. Ilgtermina programmas ir vispärïgäkas un aptver visus mërksus un var tikt izmantotas ilgāku laika periodu. İstermiņa programmas ir detalizētas un norāda, kādas darbības notiks gada laikā, kā arī sagaidāmos rezultātus. Programmas bieži jāpārskata un jäatjauno.

ISO standarts nosaka, ka uzņēmumam jāizstrādā un jāveic pasākumi, lai veiktu to savu darbību, kuras var ietekmët vidi, galveno raksturojošo lielumu monitoringu. Monitoringa rezultāti ir jāizmanto regulārai savas darbības atbilstības noteikšanai attiecīgajai vides likumdošanai un saviem nospraustajiem mērķiem.

Kā monitorings šeit ir jāsaprot gan fizikālo parametru monitorings, izmantojot dažādas instrumentālas metodes, gan arī datu vākšana, iegūstot statistisku pārskatu par esošiem rādītājiem.

Datu vākšanu veic, nosakot:

- üdens un enerğijas patērinu;

- ražošanā izlietoto izejvielu daudzumu;

- ekspluatācijai izmantotās ķīmiskās vielas utt.

Fizikālo parametru monitorings ir:

- gaisa un ūdens piesārņojuma koncentrācijas noteikšana;

- trokšña lïmena monitorings;

- temperatūras monitorings.

Uzņēmuma vadība parasti ievieš monitoringa sistēmu, kas piemērota uznēmuma darbībai, lai atvieglotu lëmumu pienemšanu. Vides aizsardzības un uzñēmuma darbības efektivitātes palielināšana vienmēr pamatojas uz atbilstošu darbības monitoringu. Spēja interpretēt monitoringa rezultätus in diezgan sarežgits process. Monitoringa rezultātu labākais atspogulıošanas veids ir izmantojot grafisko metodi.

Svarīgākie vides monitoringa izveides soli ir šādi:

- noskaidrot mērķos un uzdevumos, kādiem parametriem nepieciešams vai vēlarns monitorings;

- pieņemt lëmumu, kā tiks realizēts monitorings; 
- nolemt, cik bieži nepieciešami monitoringa dati, un nozīmēt atbildīgo par tā realizēšanu;

- izlemt, kurā struktūrvieñ̄bā tiks prezentēti monitoringā iegūitie parametri, un kādā veidā tas tiks darìts;

- izstrādāt kārtību, lai uzturētu nemainīgu monitoringa kvalitāti un veiktu rezultātu sistemātisku reǵistru.

Monitoringam ir jābūt tik biežam, lai uznēmums varētu izvērtēt atšķirību dažāà darbības posmos.

No vides aizsardzibas pasākumu viedolỵa svarīgi ir atrast attiecību starp ražošanas apjomu un piesārņojumu, piemēram, būtu ieteicams aprēkināt nedēļas energijijas patēriņu uz vienu saražoto produkcijas vienību.

Uzņēmumam jāizstrādā kārtỉba, lai identificētu un uzturētu vides stāvokḷa reǵistrāciju. Jāizstrādā noteikta kārtība visas pārvaldības sistēmas modernizēšanai. Parasti uzlabošanas pasākumi tiek veikti vienreiz gadā saskaņā ar pārvald̄̄bas apskatu. Uzņēmuma vadībai jāpärskata visa vides pārvaldỉbas sistēma, lai nodrošinātu tās nepārtrauktu efektivitāti. Pārskatam jāatspogulo vides politikas, mērķu un citu pārvald̄̃bas sistēmas elementu mainas nepieciešamību, kam atbilstoši jäbūt dokumentētam.

Jāveic bieži auditi, lai noteiktu, vai vides pārvaldības sistēma atbilst vai neatbilst plānotajai programmai un vai tā atbilstoši ieviesta un realizēta. Uzṇēmumam jārada pašam sava vides auditēšanas programma.

Lai veicinātu sabiedrības aktīvu iesaistīšanos vides problëmu risinājumos, ir jānodrošina katra konkrēta darbinieka apgāde ar plašu informāciju par pasākumiem, kādi jāveic uzņēmumā, lai uzlabotu vides kvalitāti, un jāinformē cilvēki par vinu līdzdalību vides problēmu risināšanā.

leviešot vides aizsardzības standartus, tiks garantēts vides stāvoḳ̣a uzlabojums ilgstošă laika periodā un līdz ar to arī cilvēku dzīves vides uzlabojums, kas samazinās iespējamo risku sabiedrībai un katram indivīdam, ļaus prognozēt iespējamos riska avotus un izstrādăt aizsardzỉbas koncepciju pret potenciālo risku.

Vienlaicīgi tiktu aizsargāti Latvijas patērētāji un apkārtējā vide no bīstamu produktu un pakalpojumu ietekmes, kā arī veicināta starptautiskās tirdzniecības attīstība, tirdzniecibas līgumu slēgšana starp atsevišķiem ekonomiskajiem blokiem un Latvijas uzņēmumu iekļaušanās starptautiskajā tirgū.

\title{
ИЗМЕНЕНИЯ ФИТОПЛАНКТОНА ВОДОЕМА-ОХЛАДИТЕЛЯ ЛУКОМСКОЙ ТЭС
}

\author{
* САМОЙЛЕНКО В.М., ВЕЖНОВЕЦ Г.Г.
}

Белорусский государственный университет, географический факультет, научно-исследовательская лаборатория мониторинга водньх ресурсов

* ул. Голубева 28 - 224, Минск, 220116, Белорусь

$$
\text { T.: } 2264885
$$

При проведении экологического монхторинга водньгх экосистем важное место занимает исследование сообщества планктонньх водорослей. Фитопланктон, являясь начальньпм звеном трофической цепи водоема, первьм откликается на изменение условий обитания. Реакция фитопланктона выражается в изменении 